\title{
MOLECULAR EPIDEMIOLOGICAL STUDY ON PESTE DES PETITS RUMINANTS IN EGYPT 2015
}

\author{
Wagdy R. ElAshmawy ${ }^{1 *}$, Abdelhamid I. Bazid², Mohamed Aboelkhair², Mostafa A. Sakr ${ }^{3}$, Aysam M. Fayed $^{3}$, Mohamed Fawzy $^{4}$ \\ ${ }^{1}$ Department of Internal Medicine and Infectious Diseases, Faculty of Veterinary Medicine, Cairo University, ${ }^{2}$ Department of Virology, Faculty \\ of Veterinary Medicine, University of Sadat City, Sadat city, Minoufiya, ${ }^{3}$ Molecular diagnostics and therapeutics department, Genetic \\ Engineering and Biotechnology Research Institute (GEBRI), University of Sadat City, ${ }^{4}$ Department of Virology, Faculty of Veterinary Medicine- \\ Suez Canal University, Ismailia, Egypt \\ *Corresponding author, E-mail: ubiowagdy@staff.cu.edu.eg
}

\begin{abstract}
Peste des petits ruminants (PPR) is one of highly contagious viral diseases of small ruminants with high economic losses due to the high morbidity and mortality. In Egypt, PPR in the last 10 years re-emerged again with high mortality in sheep flocks. There is no much data regarding the circulating Peste des petits ruminants' virus and the epidemiological distribution in small ruminants. The study was carried out on a sheep flock of 50 rams aged of 9-12 months with clinical signs suggestive to PPR infection (fever, erosions of the buccal mucosa, pneumonia, diarrhea high morbidity and mortality). Buffy coat and lymph nodes from diseased and dead animals were sent for diagnosis and molecular diagnosis was confirmed using RT-PCR with specific primers targeting three genes; nucleo-capsid $(\mathrm{N})$, fusion $(\mathrm{F})$, and hemagglutinin $(\mathrm{H})$. Sequencing and phylogenetic analysis was carried out on the PCR products and revealed that, the circulating virus is belonged to lineage IV along with Ethiopian strain.
\end{abstract}

Key words: peste des petits ruminants; molecular; epidemiological; diagnosis; Egypt

\section{Introduction}

Peste des petits ruminants (PPR) is a highly contagious viral disease of domestic and wild small ruminants. It's caused by RNA virus belonged to genus Morbillivirus, family Paramyxoviridae. (1) and characterized by high morbidity and mortality in affected flocks. Clinically diseased animals suffered from fever $\left(40-41^{\circ} \mathrm{C}\right)$ for 5-8 days before returning to normal during recovery or to subnormal before death, ocular-nasal discharges which starts usually serous and might end with

Received:29 May 2016

Accepted for publication: 19 June 2018 purulent discharges at late stages, erosions and ulceration of buccal mucosa, pneumonia, and ends with diarrhea which could be bloody in severe cases with high mortalities. The disease was first described in Cote d'Ivoire in 1947(2) and the infection is restricted to some African and Asian countries. Affected African countries extended from Egypt in the north to Kenya in southeast and Gabon in the west while, affected Asian countries include India, Pakistan, Bangladesh and Saudi Arabia, $(3,4)$. It has severe economic impact on animal wealth as it caused severe mortality with more than $50 \%$ of the affected animals died due to pneumonia, diarrhea and dehydration(5). PPR 
Virus is mainly transmitted by aerosol infection, and may also be spread through direct contact and/ or consumption of contaminated water or feed(6).

There are four lineages of PPR. Three lineages I, II and III have been found in Africa [West Africa (I and II), East Africa (III)] while Lineage IV has been restricted to the Middle East and Asia. Lineage III is being reported in Yemen and Oman while mixed lineages of III and IV were reported in the United Arab Emirates and Qatar. Recently lineage IV is present across the PPR endemic areas which may replace other lineages(4, 7-9). The apparent expansion of Asian lineage IV across Africa is supported by a constant increase in the incidence of disease, suggesting an increase in its virulence (9).

The control strategy of PPR in Egypt depends mainly on control of animal movement combined with ring vaccination of 5 kilometers around the affected spot using live attenuated vaccines and symptomatic treatment of the affected animals (3).

The objectives of the study were to study different epidemiological parameters including the attack rate, mortality and case fatality in a clinically infected sheep flock and genetically characterize the circulating PPRV in Egyptian small ruminant population through the phylogenetic analysis of the infecting stain.

\section{Materials and methods}

\section{Animals}

The study was carried out between May 2015 and April 2016 on a fattening sheep flock consisted of 50 rams aged 9-12 months, diseased cases started 10 days after the last purchased animals. Diseased animals suffered from fever, salivation with severe erosions in the buccal mucosa swelling of lips, anorexia, nasal discharges, increased respiratory rate and signs of pneumonia in some cases and ended with severe diarrhea which was bloody in some cases, then dehydration and death. The signs were suggestive for PPR infection, blood samples were collected during viremia and tissue samples from dead animals. The samples were sent to the Virology Laboratory at Faculty of Veterinary Medicine, Sadat City University, Egypt for confirmation.

The affected flock was examined clinically according to Jackson and Cockcroft, 2002(10). The attack rate, mortality and case fatality rates were determined according to Stevenson, 2005 (11)

Treatment was done on symptomatic basis, fluid therapy (Ringer lactate dosed at $15 \mathrm{ml} / \mathrm{kg}$ ), all the animals were given long acting oxytetracycline at a dose of $20 \mathrm{mg} / \mathrm{kg}$ (Oxitetraciclina 200LA ${ }^{\circledR}$ ) , ketoprofen (Ainil $\left.{ }^{\circledR}\right)$ at a dose of $3 \mathrm{mg} / \mathrm{kg}$ and mouth wash with betadine $1 \%$ till recovery or death according to Tariq et al. 2014 (12).

\section{RNA extraction}

RNA extraction was performed on the supernatant of pooled homogenate from tissues or buffy coat using viral gen-spin Viral DNA/RNA extraction kit (INTRON Biotechnology, Korea) according to the manufacturer's procedure. RNA concentration and integration were quantified by spectrophotometric method.

\section{RT-PCR protocol}

Stranded cDNA of the extracted RNA was firstly done using Hsien Script RH (-) cDNA synthesis kit (INTRON Biotechnology, Korea) following the manufacturer's instructions and reaction was as follow; $10 \mu 12 x$ reaction solution, $1 \mu 1$ enzyme mix, $5 \mu$ template RNA, $1 \mu 1$ specific reverse primer, DNase / RNase free water up to $20 \mu \mathrm{l}$ and the cDNA was synthesis at $42{ }^{\circ} \mathrm{C}$ for $30 \mathrm{~min}$.

Conventional RT-PCR protocol was used with 3 $\mu 1$ of the resulted cDNA in $25 \mu 1$ reaction mixtures using 2x PCR master mix solution (I-Taq) INTRON Biotechnology, Korea) with PPR-F, H, N genes specific primers as listed in Table 1 . The thermal profile was as fellow; $94 \mathrm{C}$ for $1 \mathrm{~min}, 50 \mathrm{C}$ for 1 $\mathrm{min}, 72 \mathrm{C}$ for $2 \mathrm{~min}$ extension for $\mathrm{F}$ gene, While with $\mathrm{H}$ and $\mathrm{N}$ genes, the conditions were as follow; $94 \mathrm{C}$ for 30 seconds, $55 \mathrm{C}$ for 30 seconds, $72 \mathrm{C}$ for 30 seconds for total 35 cycles and final extension for 7 minutes.

PCR products were electrophoresed on a $1.2 \%$ agarose gel in $1 \mathrm{x}$ (TAE) buffer containing ethidium bromide, then visualized and photographed using gel documentation system.

\section{Genetic analysis of $F, H$, and $N$ protein gene}

The purified RT-PCR products were sequenced directly using PCR primer specific for $\mathrm{F}, \mathrm{H}$ and $\mathrm{N}$ genes. Cycle sequencing reaction was carried out 
with Big Dye Terminator v3.1 Cycle Sequencing Kit on an Applied Biosystems 3100 automated DNA sequencer (Applied Biosystems, USA). The samples were sequenced in Animal Health Research Institute- Gene Analysis Unit. Egypt. The resulted nucleotide sequence and their transcribed amino acids were analyzed using Bio Edit (7.1.3) program Sequences, and phylogenetic trees were constructed by the neighbor joining method by bootstrap sampling of 1000 replicate using MEGA 7.

\section{Results}

\section{Clinical Findings}

The clinical examination of the diseased sheep flock revealed that, the affected flock was recently introduced in May 2015, all were rams and they were purchased from the animal market 10 days before the appearance of clinical signs. They were apparently healthy at the time of purchasing.
The attack rate was $80 \%$ (40 out of 50 ), mortality rate was $28 \%$ ( 14 out of 50 ), case fatality rate was $35 \%$ (14 out of 40 ) and the recovery rate was $65 \%$ (26 out of 40 ).

Affected animals suffered from fever, salivation with severe erosions in the buccal mucosa as in fig (1-a), ocular and nasal discharges. Some cases showed respiratory manifestations and the disease ended with diarrhea which was bloody in some cases as in fig. (1-b), then body temperature fall to subnormal and death occurred.

\section{$R T-P C R$}

All tissues and blood samples were RT-PCR positive with the three selected genes $(\mathrm{N}, \mathrm{F}, \mathrm{H})$. The PCR products were at expected sizes $351 \mathrm{bp}$, $448 \mathrm{bp}, 328 \mathrm{bp}$ for $\mathrm{N}, \mathrm{F}$, and $\mathrm{H}$ genes respectively. The PCR bands of $\mathrm{N}$ gene are more clear and thick compared to PCR bands of $\mathrm{F}$ and $\mathrm{H}$ genes.

Table 1: Primers of peste des petite ruminants

\begin{tabular}{|c|c|c|c|c|c|}
\hline Gene & Primer & Sequence & Position & Size & Reference \\
\hline \multirow{2}{*}{ F-gene } & PPRV F1b & $5^{\circ}$-AGT ACA AAA GAT TGC TGA TCA CAG T-3’ & $760-784$ & \multirow[t]{2}{*}{$448 \mathrm{bp}$} & \multirow[t]{2}{*}{$(13)$} \\
\hline & PPRV F2d & $5^{\circ}$-GGG TCT CGA AGG CTA GGC CC GAA TA-3 & $1207-1183$ & & \\
\hline \multirow{2}{*}{$\mathrm{N}$-gene } & NP3 & $5^{\circ}$-TCT CGG AAA TCG CCT CAC AGA CTG -3- & $1232-1255$ & \multirow[t]{2}{*}{$351 \mathrm{bp}$} & \multirow[t]{2}{*}{ (14) } \\
\hline & NP4 & $5^{\circ}$-СCT CCT CCT GGT CCT CCA GAA TCT $-3^{-}$ & $1583-1560$ & & \\
\hline \multirow{2}{*}{ H-gene } & Pprh_fr 1 & $5^{\circ}$-TGT CAT GTT CTT ATA GAG TT-3’ & $1500-1519$ & \multirow[t]{2}{*}{$328 \mathrm{bp}$} & \multirow[t]{2}{*}{$(15)$} \\
\hline & Pprh_re2 & $5^{\circ}$-GAC TGG ATT ACA TGT TAC CT-3’ & $1847-1828$ & & \\
\hline
\end{tabular}

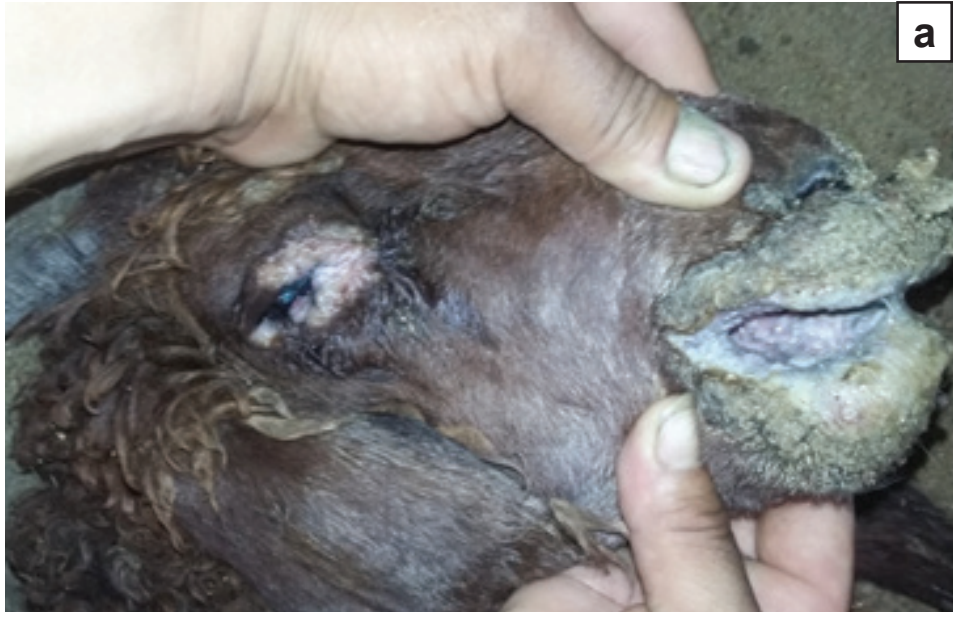

Figure 1: a- Sheep has severe mouth lesions, nasal and ocular discharges; $b$ - Sheep with severe diarrhea at the end of the disease

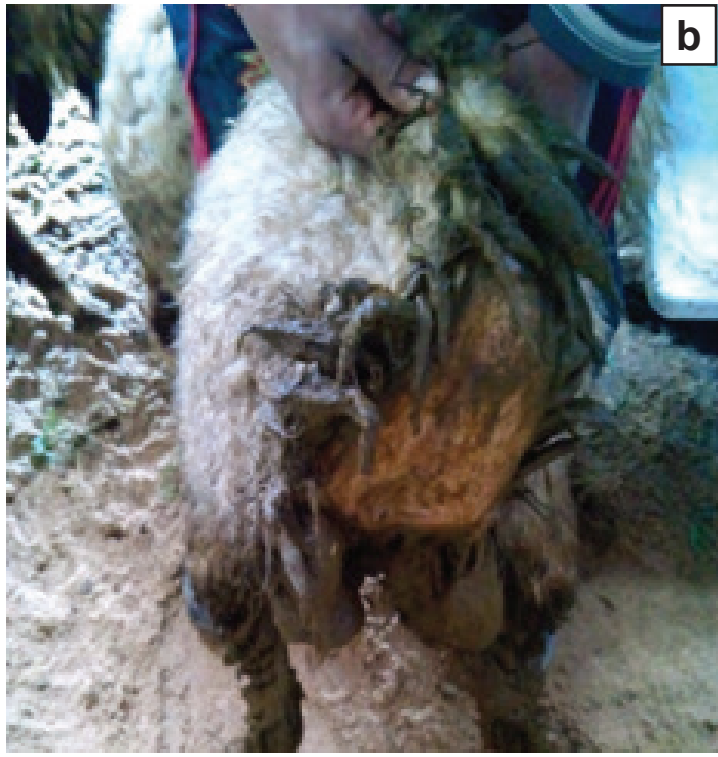


Table 2: Accession number for the PPR sequence from blood and tissue samples

\begin{tabular}{|l|l|l|l|}
\hline & Strain & Accession number & Characters \\
\hline 1- & Egypt/Giza-1/2015 & KX189061 & PPR-Egypt-2016-blood(F-gene) \\
\hline 2- & Egypt/Giza-2/2015 & KX189060 & PPR-Egypt-2016-Tissue(F-gene) \\
\hline 3- & Egypt/Giza-3/2015 & KX189062 & >PPR-Egypt-2016-blood(H-gene) \\
\hline 4- & Egypt/Giza-4/2015 & KX189063 & >PPR-Egypt-2016-Tissue(H-gene) \\
\hline 5- & Egypt/Giza-5/2015 & KX189064 & PPR-Egypt-2016-blood(N-gene) \\
\hline 6- & Egypt/Giza-6/2015 & KX189065 & PPR-Egypt-2016-tissue(N-gene) \\
\hline
\end{tabular}

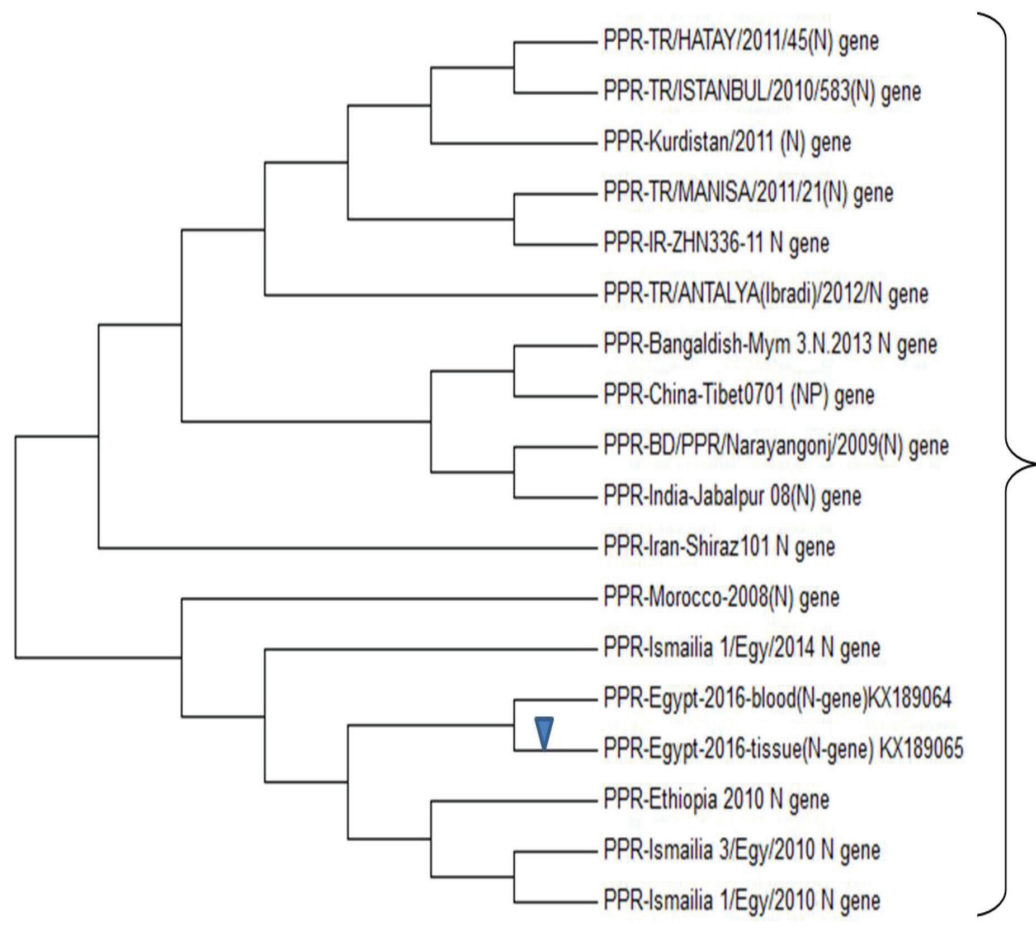

\section{Lineage IV}

Figure 2: Phylogenetic tree of nucleotide sequences of partial nucleocapsid protein $(\mathrm{N}$ gene fragment of PPRV isolated from Egypt and reference strains from GenBank database. MEGA 7 program was used to generate the tree. Arrow head referee to isolates under study

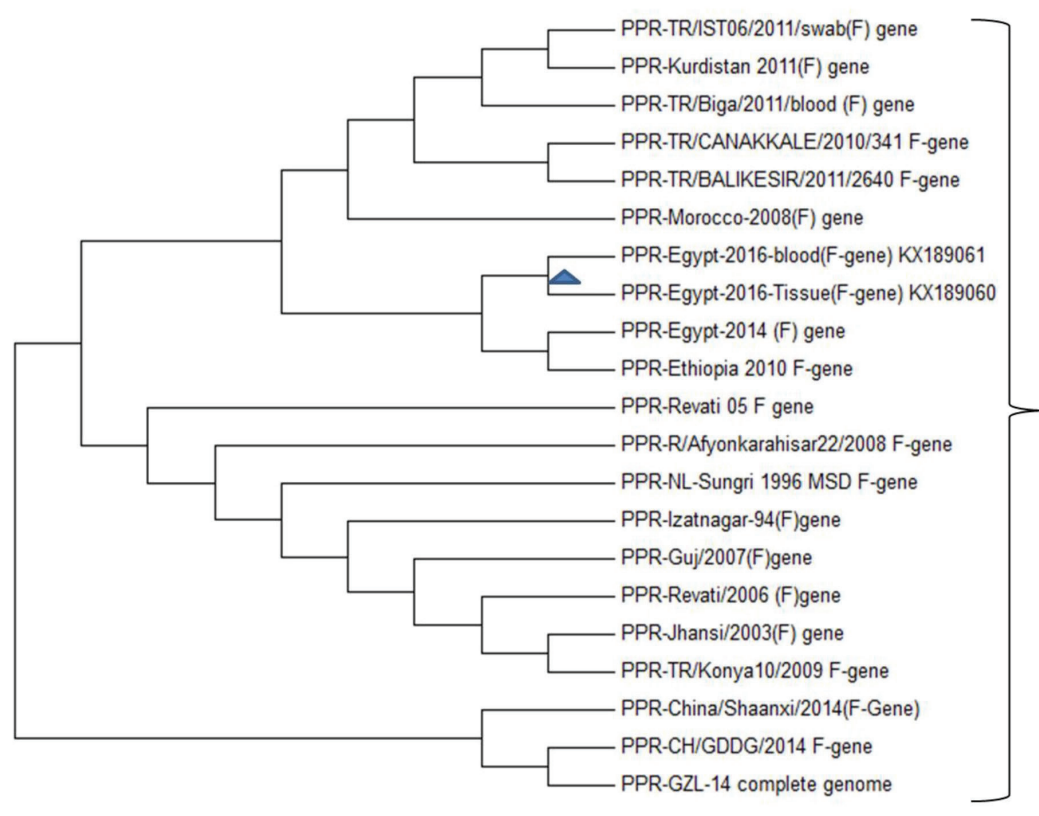

Lineage IV

Figure 3: Phylogenetic tree of nucleotide sequences of partial fusion gene fragment of PPRV isolated from Egypt and reference strains from GenBank database. MEGA 7 program was used to generate the tree. Arrow head referees to isolates under study 


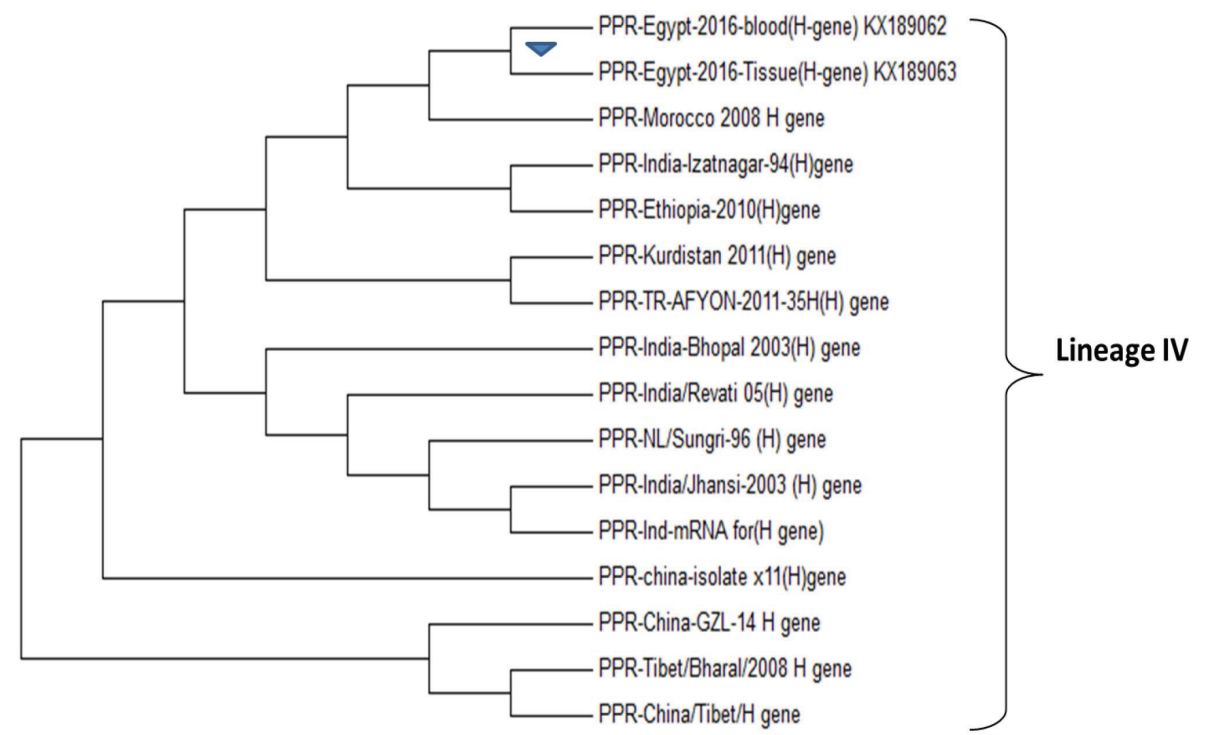

Figure 4: Phylogenetic tree of nucleotide sequences of partial hemagglutinin protein $(\mathrm{H}$ gene fragment of PPRV isolated from Egypt and reference strains from GenBank database. MEGA 7 program was used to generate the tree. Arrow head referes to isolates under study
The nucleotide and amino acid analysis of partial $N, F$, and $H$ genes

The nucleotide sequence analysis of $\mathrm{N}$ gene showed no characteristic difference between the PPRV of the current study and other PPRV sequences except at position 1255 where PPRV of the recent study showed guanine at this position in contrast to adenine for other isolates. $\mathrm{N}$ gene sequences of PPRV strains detected in both tissues and blood of affected animals have shown no nucleotide difference. The amino acid analysis showed characteristic difference at position 452 between the detected strain of this study and the remaining isolates including previous Egyptian isolates.

For $\mathrm{F}$ gene, there were nucleotide differences between the PPRV of the current study and other PPRV sequences at positions $314,552,645$. F gene sequences of PPRV strains detected in both tissues and blood of affected animals have shown high nucleotide homology.

The amino acid analysis showed characteristic difference at position 20 between the detected strain of this study (sequences detected from blood) and the remaining isolates including previous Egyptian isolates.

For $\mathrm{H}$ gene, there were nucleotide differences between the PPRV of the current study and other PPRV sequences at positions 1662, 1776, 1778. H gene sequences of PPRV strains detected in both tissues and blood of affected animals have shown no nucleotide difference. The amino acid analysis showed characteristic difference at positions 589 , 596 between the detected strain of this study and the remaining isolates including previous Egyptian isolates.

The phylogenetic analysis of the detected $P P R V$ based on partial sequences of $N, F$, and $H$ genes

For $\mathrm{N}$ gene, the detected strain of the current study clustered with the previous Egyptian isolates in one cluster including PPRV isolated in Ethiopia 2010 (Fig. 2).

For $\mathrm{F}$ gene, the detected strain of the current study clustered with a previous Egyptian isolate (PPRV Egypt 2014) and PPRV Ethiopia 2010 in the same cluster (Fig.3).

For $\mathrm{H}$ gene, the detected strain of the current study clustered with a PPR Morocco 2008 in the same cluster which is very close to PPR Ethiopia 2010 and PPR India Izatnagar-94 (Fig.4).

\section{Discussion}

Peste des petite ruminants is one of the important economical viral diseases of small ruminants. In Egypt, PPRV was first detected in 1987 (13). Later, few reports described the disease in Egyptian small ruminants $(1,14,15)$ and this might be due to absence of animal records of sheep and goats, PPR can be misdiagnosed with other diseases that cause respiratory problems and mortality of 
small ruminants also animal health workers and livestock owners in the areas were not familiar with its clinical and pathological features $(3,16)$.

Clinical signs of PPR occurred 1010 days after purchasing of the rams from the market which indicated that they were at the incubation period. The infection might occured at the market which could provide a potential source of transmission and spreading of different diseases. The attack rate of the disease was $80 \%$ which indicate the contagiousness of the disease, the mortality rate was $28 \%$ while the case fatality rate was $35 \%$ and these results are comparable with the results of the previous studies (17-20).

Overall, the data regarding the genetic characterizations and epidemiological distributions of PPR in Egypt are still relatively rare. The study aimed to genetically characterize the circulating PPRV in Egyptian small ruminant population.

Molecular diagnosis of PPRV was carried out through detection of fusion $(\mathrm{F})$, nucleocapsid $(\mathrm{N})$, and $(\mathrm{H})$ hemagglutinin genes-based RT-PCR in tested clinical samples from the buffy coat and lymph nodes. All tested samples showed PCR bands at the expected sizes. The PCR bands of $\mathrm{N}$ gene were clearer than bands of other genes. It was suggested that $\mathrm{N}$ gene-based PCR is more sensitive. Because $\mathrm{N}$ messenger RNA is produced more during PPRV infection (2).

PPR viruses are classified into four lineages (I, II, III and IV) that vary genetically $(21,22)$. The partial regions of $\mathrm{N}, \mathrm{F}$ or $\mathrm{H}$ genes are used for the phylogenetic tree analysis and it is clearly defined four different lineages of PPRV. In the current study, the genetic data generated, and RT-PCR results confirmed that the clinical disease observed in affected animals was caused by PPRV and the virus belonged to lineage IV(23).

The analysis of $\mathrm{N}$ gene sequence of PPRV is most suitable for phylogenetic difference of close viruses and provides an inclusive view of PPR molecular epidemiology $(2,21,24)$. In this study, the $\mathrm{N}$ gene primers used encompass the region of nucleotides 1253 to 1470 of the $\mathrm{N}$ gene which is more variable. The amino acid analysis showed characteristic difference at position 452 between the detected strain of this study and the remaining isolates including previous Egyptian isolates. In the nucleotide sequence analysis, there was no characteristic difference between the PPRV of the current study and other PPRV sequences except at position 1255 where PPRV of the recent study showed guanine at this position in contrast to adenine for other isolates. In the phylogenetic analysis, the detected strain of the current study clustered with the previous Egyptian isolates in one cluster including PPRV isolated in Ethiopia 2010 (Fig. 2).

The analysis of $F$ gene sequence of the PPRV of the study showed characteristic features like $\mathrm{N}$ gene analysis. In the nucleotide sequence analysis, there were differences between the PPRV of the current study and other PPRV sequences at positions $314,552,645$. The amino acid analysis showed characteristic difference at position 20 between the detected strain of this study (sequences detected from blood) and the remaining isolates including previous Egyptian isolates. In the phylogenetic analysis, the detected strain of the current study clustered with a previous Egyptian isolate (PPR Egypt 2014) and PPR Ethiopia 2010 in the same cluster (Fig.3). It was reported the phylogenetic trees using the $\mathrm{F}$ gene data produced a limited number of clusters that although supported by bootstrap support, did not split isolates according to geographical isolation(2).

The analysis of $\mathrm{H}$ gene sequence of the PPRV of the study showed characteristic features as follow: In the nucleotide sequence analysis, there were differences between the PPRV of the current study and other PPRV sequences at positions $1662,1776,1778$. The amino acid analysis showed characteristic difference at positions 589, 596 between the detected strain of this study and the remaining isolates including previous Egyptian isolates. In the phylogenetic analysis, the detected strain of the current study clustered with a PPR Morocco 2008 in the same cluster which is very close to PPR Ethiopia 2010 and PPR India Izatnagar-94 (Fig.4). $\mathrm{H}$ gene of PPRV is more variable than the $\mathrm{F}$ gene so the phylogenetic relatedness of isolates is more properly determined with respect to geographical isolation than when comparing the $\mathrm{F}$ gene data. It was also stated that although the $\mathrm{H}$ gene partial sequence data are rare compared to $\mathrm{N}$ and $\mathrm{F}$ gene partial sequence data, phylogenetic analysis using these data shows the formation of different clades that are divided into sub-clusters(2).

The PPR viruses detected in Egypt could not have been derived from the vaccine strain because the vaccine virus belongs to lineage II while the field isolates belongs to lineage IV. 
Symptomatic treatment has a significant role in the recovery of the affected animals. Systemic antibiotics prevent the secondary bacterial infections and anti-inflammatory reduced the inflammation also fluid therapy restores the body fluids and nutritional supplement in absence of good appetite. The recovery rate in the study was $65 \%$ and these results agreed with Tariq et al. 2014 (12).

\section{Conclusion}

Peste des petite ruminants is detected in 2015 from an outbreak in sheep flock and the virus still circulating in Egypt and resulted in 28\% mortality in the affected flock. Molecular data of the study provides an evidence for circulation of PPRV in Egyptian small ruminant flocks. The circulating PPRV is phylogenetically related to lineage IV which is in one cluster with the Ethiopian isolates in 2010. Further studies with large numbers of animals from different governorates are essentially required. Further epidemiological data regarding the prevalence of the disease, spatial and temporal distribution and evaluation of preventive measures are required. Symptomatic treatment plays a significant role in the recovery of diseased animals and need to evaluate the roles of different drugs and the effect on different hematological and biochemical parameters. All the Authors declare that there is no conflict of interest.

\section{References}

1. Banyard AC, Parida S, Batten C, Oura C, Kwiatek O, Libeau G. Global distribution of peste des petits ruminants virus and prospects for improved diagnosis and control. J Gen Virol 2010; 91(12): 2885-7.

2. Kumar KS, Babu A, Sundarapandian G, et al. Molecular characterisation of lineage IV peste des petits ruminants virus using multi gene sequence data. Vet Microbiol 2014; 174(1/2): 39-49.

3. Roeder P, Obi T. Recognizing Peste des petits ruminants: a field manual. Rome : FAO, EMPRES, 1999: 28 p.

4. EFSA Panel on Animal Health and Welfare. Scientific Opinion on peste des petits ruminants. EFSA Journal. 2015;13(1): e3985 (94 p.)

1. https://efsa.onlinelibrary.wiley.com/doi/pdf/ 10.2903/j.efsa.2015.3985

5. Sharma A, Kumar A, Sharma P. Goat and sheep plague a fatal disease of small ruminants Livest Int 2007; 11(6): 2 .

6. Tariq A. An easy approach towards diagnosis of Peste des petits ruminants (PPR) through clinical examination. Res J Vet Pract 2014; 2(1S): $1-3$.

7. Kwiatek O, Ali YH, Saeed IK, et al. Asian lineage of Peste des petits ruminants virus, Africa. Emerg Infect Dis 2011; 17(7): 1223-31.

8. Libeau G, Diallo A, Parida S. Evolutionary genetics underlying the spread of peste des petits ruminants virus. Anim Front 2013; 4(1): 14-20.

9. Muniraju M, Mahapatra M, Ayelet G, et al. Emergence of lineage IV Peste des petits ruminants virus in Ethiopia: complete genome sequence of an Ethiopian isolate 2010. Transbound Emerg Dis. 2016; 63(4): 435-42.

10. Jackson P, Cockcroft P. Clinical examination of farm animals. Oxford : Blackwell Publishing, 2002: $450 \mathrm{p}$.

11. Stevenson M. An introduction to veterinary epidemiology. Palmerston North : EpiCentre, IVABS, Massey University, 2005: 90 p.

12. Tariq A, Aqil K, Akbar Z, et al. Peste des petits ruminants (PPR) in small ruminants: a clinical, haemato-serological and pathological aspects. Int J Vet Sci 2014; 3(4 ): 206-9.

13. Abd El-Rahim I, Sharawi S, Barakat M, El-Nahas E. An outbreak of peste des petits ruminants in migratory flocks of sheep and goats in Egypt in 2006. Rev Sci Techn 2010; 29: 655-62.

14. Soltan MA, Abd-Eldaim MM. Emergence of peste des petits ruminants virus lineage IV in Ismailia Province, Egypt. Infect Genet Evol 2014; 28: 44-7.

15. Parida S, Muniraju M, Mahapatra M, Muthuchelvan D, Buczkowski H, Banyard AC. Peste des petits ruminants. Vet Microbiol 2015; 181(12): 90-106.

16. Tibbo M, Woldemeskel M, Gopilo A. An outbreak of respiratory disease complex in sheep in Central Ethiopia. Trop Anim Health Prod 2001; 33(5): 355-65.

17. Cebra C, Cebra M. Diseases of the hematologic, immunologic, and lymphatic systems (Multisystem diseases). In: Pugh DG, Baird AN, eds. Sheep and goat medicine. $2^{\text {nd }}$ ed. St Louis : W.B. Saunders, 2012: 466-502.

18. El Arbi AS, El Mamy AB, Salami H, et al. Peste des petits ruminants virus, Mauritania. Emerg Infect Dis 2014; 20(2): 334-6.

19. Chowdhury EH, Bhuiyan AR, Rahman MM, 
Siddique MSA, Islam MR. Natural peste des petits ruminants virus infection in Black Bengal goats: virological, pathological and immunohistochemical investigation. BMC Vet Res 2014; 10: e263. https: / / bmcvetres.biomedcentral.com/articles/10.1186/s12917-014-0263-y

20. Shaila MS, Shamaki D, Forsyth MA, et al. Geographic distribution and epidemiology of peste des petits ruminants viruses. Virus Res 1996; 43(2): 149-53.

21. Kerur N, Jhala MK, Joshi CG. Genetic characterization of Indian peste des petits ruminants virus (PPRV) by sequencing and phylogenetic analysis of fusion protein and nucleoprotein gene segments. Res Vet Sci 2008; 85(1): 176-83.

22. Couacy-Hymann E, Roger F, Hurard C, Guillou JP, Libeau G, Diallo A. Rapid and sensitive detection of peste des petits ruminants virus by a polymerase chain reaction assay. J Virol Methods 2002; 100(1/2): 17-25.

23. Kwiatek O, Minet C, Grillet C, et al. Peste des petits ruminants (PPR) outbreak in Tajikistan. J Comp Pathol 2007; 136(2/3): 111-9.

24. Munir M, Zohari S, Suluku R, et al. Genetic Characterization of Peste des petits ruminants virus, Sierra Leone. Emerg Infect Dis 2012; 18(1): 193-9.

\title{
MOLEKULARNA EPIDEMIOLOŠKA ŠTUDIJA KUGE DROBNICE V EGIPTU LETA 2015
}

\author{
W. R. ElAshmawy, A. I. Bazid, M. Aboelkhair, M. A. Sakr, A. M. Fayed, M. Fawzy
}

Povzetek: Kuga drobnice (PPR; iz angl. peste des petits) je ena izmed zelo nalezljivih virusnih bolezni malih prežvekovalcev, ki zaradi visoke obolevnosti in umrljivosti povzroča visoke gospodarske izgube. V Egiptu se je v zadnjih desetih letih PPR znova pojavila z visoko smrtnostjo priovcah.

O kugi drobnice in epidemiologiji te bolezni pri malih prežvekovalcih v literaturi ne najdemo veliko podatkov. Opisana raziskava je bila opravljena v čredi 50 ovnov, starih od 9 do 12 mesecev, s kliničnimi znaki, ki so kazali na prisotnost bolezni PPR (zvišana telesna temperatura, erozije ustne sluznice, pljučnica, driska, visoka obolevnost in smrtnost). Za natančno diagnosticiranje bolezni je bil uporabljen del krvi, pridobljen s centrifugiranjem, ki vsebuje veliko levkocitov in trombocitov (angl. Buffy coat) in bezgavke obolelih in mrtvih ovnov. Zuporabo specifičnih oligonukleotidov za določanje prisotnosti nukleotidne $(\mathrm{N})$, fuzijske $(\mathrm{F})$ in hemaglutininske (H). beljakovine v reakciji RT PCR smo na molekularnem nivoju potrdili prisotnost okužbe s povzročiteljem PPR. Analiza zaporedja genov in filogenetske analize so bile izvedene na produktih analize PCR, pri tem pa smo ugotovili, da virus pripada liniji IV skupajz etiopijskim sevom.

Ključne besede: kuga drobnice; molekularna diagnostika; epidemiologija; Egipt 